\title{
'Jeg ser en lighed mellem mig og kartofler’
}

\author{
Reproduktivt arbejde iskandinavisk poesi
}

Fra 1960'erne og frem dukker bestemte motiver op på en ny måde i den skandinaviske poesi. Især yngre, kvindelige forfattere skriver om og fra det reproduktive arbejdes sted - det vil eksempelvis sige fra rengøringens, madlavningens og børnepasningens sted. Eller mere generelt: Det usynliggjorte arbejdes sted. Den enkle tese, som jeg fremsætter her, er, at disse tekster syn- og sanseliggør det usynliggjorte, reproduktive arbejde som rigtigt, virkeligt, værdifuldt arbejde, hvilket i sig selv er en lille revolution.

Jeg skal fremdrage en lille håndfuld litterære eksempler på, hvordan denne synliggørelse finder sted - der er oplagt mange flere, jeg har i denne sammenhæng forsøgt at vælge de tydeligste - og vi begynder med den kartoffelskrælning, der indgår i Inger Christensens Alfabet (1981).

Alfabets kartoffelskrælning er placeret på det sted i digtsamlingen, hvor den atombombe, som for så vidt allerede er til stede i digtsamlingens første linjes abrikostræer (abrikosens glødende farve, dens egenskab af at være en kernefrugt), pludselig, ligesom Hiroshima og Nagasaki, nævnes eksplicit. Stilen i denne del af bogen er anderledes end i resten af digtene. Der er absolut fokus på den referentielle funktion, sproget er hvidbogsagtigt, matter-of-fact-agtigt: Ingen poetiske flugtlinjer synes mulige, når de dødes antal skal gøres op. Måske fordi det ubegribelige bliver begribeligt præcis via denne nøgternhed jf. Susan Sontags kriterium om håndgribelig faktualitet som en nødvendighed, hvis de andres smerte, den vold, som bliver begået langt fra ens egen hverdag, skal blive virkelig for os. Det er hovedargumentet i Sontags bog Regarding The Pain of Others (2003), og det synes at være præcis, hvad også Alfabet peger på med den overraskende deiksis, som følger opregningen af de døde:

(f jeg står i mit køkken og skræller kartofler; vandhanen løber og overdøver næsten børnene ude i gården; 
børnene råber og

overdøver næsten

fuglene ude i

træerne; fuglene

synger og overdøver

næsten bladenes

hvisken i vinden;

bladene hvisker

og overdøver næsten

med stilhed himlen,

himlen der lyser,

og lyset der næsten

fra dengang har lignet

atombombens ild

lidt (s. 406-7)

Den forbindelse, teksten forsigtigt (jf. "næsten", "lidt") etablerer mellem Hiroshima, Nagasaki og kartoffelskrælning, er langt fra en profanering af den menneskeskabte undergangsmaskine, som atombomben klart nok er. Og lige netop ved at forbinde det abrikosgule kernelys fra Hiroshima og Nagasaki med den, i hvert fald i de nordiske lande, mest hverdagslige syssel af dem alle, kartoffelskrælning, annullerer digtet atombombens uvirkelige uopfattelighed, hvilket bestemt ikke gør atombomben mindre uhyggelig: At trække en forbindelseslinje mellem det reproduktive arbejde, det hverdagslige, livsopretholdende arbejde, som kartoffelskrælning er, og bombens exceptionelle, absolut livsnedbrydende arbejde er - vil jeg hævde - en vild politisk gestus. Det er en læsning, der kræver en kort teoretisk forklaring af husarbejdets status, hvorfor vi nu vil aflægge et kort besøg hos den feministiske bevægelse Wages for Housework.

\section{Reproduktivt/produktivt arbejde, hvad betyder det?}

Kartoffelskrælning og i det hele taget husarbejde, hvilket vi i udvidet forstand også kan kalde reproduktivt arbejde, er motiver, der er den mandsdominerede/patriarkalsk funderede litteratur, både den som handler om arbejde og også bare i det hele taget, så godt som fremmed. Selv i dag findes det synspunkt, at rengøring, madlavning, børnepasning, svangerskab, fødsel, ældrepleje og deslige er trivielle motiver, som lugter af det angiveligt kedelige private i stedet for af det angiveligt stimulerende universelle. Da de kvindelige forfattere i 60'erne og 70'erne begynder at skrive om deres (hus-)arbejde, opfattes det da heller ikke som om, de skriver om at arbejde, men som om de skriver om private (kvinde-)erfaringer, der nok kan være vigtige for dem selv, men som er uvæsentlige i et større, historisk (klassekamps-) perspektiv. Dette problem analyseres især af Selma James, Mariarosa Dalla Costa og Silvia Federici bl.a. i de to førstnævntes klassiske kampskrift: The Power of Women and the Subversion of the Community (1973) og i Federicis Wages for Housework 
(1975). Deres arbejde katalyserer en faktisk global, men britisk, amerikansk og italiensk centreret bevægelse, som helt enkelt hedder Wages for Housework, og som har som hovedkrav at reproduktivt arbejde aflønnes på samme måde som produktivt arbejde.

Kravet er naturligvis først og fremmest retorisk. Meningen med kampagnen er at synliggøre kvinders arbejde som et arbejde, der er ligeså vigtigt som at arbejde på en Fiat-fabrik. Kvinderne ønsker ikke at udregne, hvad det præcis skal koste at stryge et sygt barn over kinden eller at støvsuge. Det, de peger på, er selve arbejdsdelingens usynliggørende og marginaliserende virkninger, hvilket Karl Marx ikke tænker ind $i$ et reproduktion/produktions-perspektiv. Denne arbejdsdeling er ikke en historisk konstant, endskønt kvinder altid har båret børn. Federici analyserer dens konsolidering i den epokegørende analyse af hekseforfølgelserne, hun fremsætter i Caliban and The Witch. Women, The Body and Primitive Accumulation (2004), hvor hun knytter den kønnede arbejdsdeling til den oprindelige akkumulation. Ifølge Federici hænger hekseforfølgelserne direkte sammen med overgangen fra det senfeudale samfund til den tidlige kapitalisme. Kapitalismen begynder (jf. Marx, som Federici hele tiden trækker på, men feminismekorrigerer) præcis med den "oprindelige akkumulation", hvilket indbefatter en omfattende privatisering af dyrkningsarealer og fællesområder som skove og marskområder og etableringen af en pengeøkonomi (i stedet for en bytteøkonomi) med lønarbejde og det heraf følgende "frie marked", hvor det gælder om at købe billigt og sælge dyrt.

Den oprindelige akkumulations arbejdsdeling og medfølgende udgrænsning af reproduktionen til et særfelt, der kan underkastets drakonisk kontrol, er den historiske baggrund for hekseforfølgelserne, og uden at gå i detaljer kan man nøjes med at konstatere, at hvad, der motiverer hekseforfølgelserne, overhovedet ikke er et pludseligt opstået vanvid, hvilket i øvrigt er en ganske udbredt idé. De skal betragtes som et led i den tidlige kapitalistisk-patriarkalske ordens ønske om at opnå kontrol med reproduktionen og lønarbejdet, hvilket ikke bare cementerer opdelingen i reproduktivt (ulønnet) arbejde / produktivt (lønnet) arbejde, men jo også indstifter en ny form for patriarkat, idet kvinderne fordrives fra det fælles arbejdsrum. Også forstået som de fælles arealer man plejer at kalde The Commons (eller Fællederne).

I stedet for at have adgang til disse naturressourcer bliver kvinden selv en naturressource, der sådan set eksisterer uden for markedet og derfor kan udbyttes efter forgodtbefindende af selvsamme marked. I slutningen af 1600-tallet er processen fuldført, og den vilde og farlige "heksekvinde", der skal "tæmmes", afløses af et andet dominerende kvindebillede, den englelige husmoder, der opfylder sin blide bestemmelse i hjemmets trygge rammer, hvilket selvfølgelig ikke betyder, at den dæmoniserede repræsentation ikke stadig er den dialektiske modpart. Det er blandt andet den historie, Federici har systematiseret for os, og det er (i parentes bemærket) også denne, i høj grad fortrængte, baggrund, som vi skal forholde os til, hvis vi vil arbejde for en forandring af vores relation til planeten jorden. En økofeministisk synsvinkel på dette (som den bl.a. er blevet præsenteret af Vandana Shiva) ville være, at af-kapitalisering af landbruget - og en anden form for arbejdsdeling og værdisætning af arbejdet - er nøglen til bæredygtige samfund.

Hvad Federicis analyse har med Inger Christensens kartoffelskrælning og 60'ernes og 70'ernes kvindelitteratur at gøre, er forhåbentlig indlysende: Alene det at 
synliggøre det reproduktive arbejde, at tilskrive det værdi (både kapitalisérbar og ikke-kapitalisérbar værdi) er en radikal, revolutionerende handling alene derved, at det peger på arbejdsdelingens absolutte, ulighedsskabende uretfærdighed. Og det er dét, som Hans-Jørgen Nielsen både forstår - og så alligevel ikke helt forstår da han i 1971 modtager Kirsten Thorups I dag er det Daisy til anmeldelse i Dagbladet Information.

\section{Skraldespanden og supemarkedet}

4 På trappen ligger et lille vådt paplåg og noget af en tomat og æggeskaller og hun går ud på gaden og går ind ad en dør lige ved siden af hovedtrappen og går gennem en lang gang og kommer til døren ud til gården og åbner og hun er ude i gården og alle 3 skraldespande er uden låg og overfyldte og hun stiller sin pose hen til 10-12 andre fyldte papir- og plastikposer som står ved siden af skraldespandene og hun ser ned i poserne (Thorup 1971, 48-9)

Citatet ovenfor er fra tekststykket "Maria går ned i gården med en fyldt skraldepose" og beskriver en handling, som i allerhøjeste grad tilhører husarbejdets usynlige, evigt gentagelige sfære. Personerne i den poetiske prosabog er også blottet for markeret singularitet. Deres identiteter fremstår statiske, måske endda tomme udskiftelige.

Hans-Jørgen Nielsen skriver i sin anmeldelse af I dag er det Daisy i Information, at "alt er udvendighed, døde porer, i denne skrift", og at "tiden er uden nogen eksakt ordnende betydning i denne skrift", hvilket meget godt beskriver de korte prosateksters blandede fokaliseringer og absolutte suspendering af tiden og stedets enhed: Vi véd ikke, hvor vi er - i Italien, måske i København - inde i hovedet på Maria eller Carlo eller Rita eller måske hvem som helst. Hans-Jørgen Nielsen mener dertil, at bogen er en "tilstandsbeskrivelse" og kommer i den forbindelse ind på at den muligvis har et feministisk ærinde:

Uf Det er kvindefigurerne og deres verden, der udgør bogens tyngdepunkt. Kvinder er allerede som kvinder gjort til ting og er derfor udsat for en dobbelt tingsliggørelse i dette samfund. Det er min fornemmelse at bogen bl.a. handler om hvordan sådan noget føles. De rødstrømper der har talt om nødvendigheden af en særlig kvinde-psykiatri vil muligvis kunne hente meget mere her end det, jeg har kunnet afdække.

Det er jo ikke forkert, at I dag er det Daisy også kunne handle om, hvordan det føles at være "dobbelt tingsliggjort", dvs. både tingsliggjort af fremmedgørende arbejde (Marx) og, jf. Simone de Beauvoir, tingsliggjort af at være placeret som immanensens sted overfor det transcendentale subjekt. I Beauvoirs klassiske analyse af den patriarkalske orden i Le Deuxième Sexe (1949) indtager "manden" det transcenden- 
tale subjekts plads, fordi han kan overskride sin bundethed til kroppen, dvs. tænke systematisk og rationelt, dvs. politisk og ikke mindst filosofisk. Kvinden er heroverfor framet som ren kropslighed. Hun er kort sagt styret af sin (reproduktive) biologi og derfor ude af stand til at agere rationelt på almenvellets vegne (hun kan ikke "filosofere"), og dette repræsentationsskema er naturligvis, hvad den patriarkalske orden er bygget på.

Min pointe her er den, at teksten faktisk viser andet frem end denne "dobbelte tingsliggørelse", nemlig det reproduktive arbejdes virkelighed. Det tekststykke, hvor "Maria går ned i gården med en fyldt skraldepose" er grundlæggende parataktisk: "og, og, og, og, og, og" kæder den nøgterne beskrivelse af skraldeposenedbæringens realiteter sammen, og endskønt dette mimer det aspekt ved en reproduktiv handling, som er gentagelsen, så fungerer den rytmiske repetition også affirmativt, insisterende, fremhævende. Men vigtigst af alt er den minutiøse beskrivelse af en aldeles uspektakulær aktivitet. Tomaten, æggeskallerne, det våde paplåg er ting, som făr deres eget liv i denne beskrivelse - de bliver næsten en form for vibrant matter (Jane Bennett) - hvilket dels peger langt frem i den feministiske teoridannelseshistorie (nymaterialisme), dels peger på den marginaliseredes sensibilitet i forhold til andre/andet ligeledes marginaliserede/marginaliseret liv.

Hans-Jørgen Nielsen har én anke mod I dag er det Daisy. Og den er temmelig alvorlig. Det kan være meget godt med en "tilstandsbeskrivelse" af den "dobbelte fremmedgørelse", men det er også at ville for lidt:

6f Man kan måske kritisere bogen ideologisk på dette punkt [det tilstandsbeskrivende] for i for høj grad at skildre fangenskabet som definitivt og ikke socialt ophæveligt. Dog må det siges at bogen rummer et enkelt utopisk digt, "Forår i Peking", hvor alene lokaliseringen antyder hvor hunden ligger begravet.

Hvis vi ser bort fra det mulige forår i Peking indeholder I dag er det Daisy altså - for Hans-Jørgen Nielsen - ikke noget håb om en anden verden, den giver ingen anvisninger på, hvordan ophævelsen af den kapitalistiske undertrykkelse bliver mulig: Den mangler helt enkelt et håbefuldt, revolutionært potentiale. Trods Nielsens grundlæggende, sympatetiske indstilling til projektet ser han ikke andet end en tematisering af fremmedgørelsen i det, og problemet er, at han ikke ser, hvad der også sker her: At det usynliggjorte, reproduktive arbejde syn- og sanseliggøres som rigtigt, virkeligt, værdifuldt arbejde. Et arbejde, der dels bliver vist frem i en fin bog, der udkommer på Gyldendal, dels har fået anmelderen til at hive mange fine fremmedord op ad posen. Dét er revolutionært i samme forstand, som det er revolutionært når Wages for Housework kræver løn for at lave mad og passe børn. Og et fokus på arbejdsdelingens repressive konsekvenser burde bestemt ikke kun være interessant for dem, som han i det allerede citerede citat omtaler som "rødstrømper der har talt om nødvendigheden af en særlig kvinde-psykiatri."

I romanen Baby (1973) tager Thorup et skridt videre i samme retning, dvs. i retning af at opløse den kønsfunderede arbejdsdeling, idet hun lader to mænd, Ric og Ivan, agere hjemmegående husfædre for den udearbejdende Susi: "Ric havde købt blomster, lyserøde nelliker og han havde fået dem billigt, 8 for 2,50 og han var ved 
at arrangere dem til en pæn buket i et syltetøjsglas" (s. 152), men syltetøjsglasset vælter, og aftensmaden, fiskefileter og kartofler, brænder på, så de må skrabe det sorte af. Ric overvejer situationen: "Fiskefiletter og kartofler er det hvad vi kan præstere sagde han. Hun skulle ha noget bedre, hun arbejder hele dagen mens vi ligger og snorker" (s. 153). Og samme roman opviser desuden den mest utrolige, pop-artinspirerede, komsumkritiske, fælles, men også køns- og arbejdsdelte indkøbsscene, jeg mindes at være stødt ind i dansk litteratur, den er et tableau vivant, hvorfor jeg tillader mig at citere et længere stykke. David, Karla og Karlas søn Frans skal i supermarkedet $\mathrm{HB}$, men hvad skal de have:

46

Vi skal ha kød og pålæg og æg og et par strømpebukser, sagde hun og David tænkte på at købe en flaske vin og Karla blev stående foran grøntsager \& frugt og hun kunne ikke huske om hun skulle købe æbler og de gik videre og David lagde en dåse rejer ned i kurven. Skal vi ikke ta nogen færdiglavede frikadeller og så varme dem i morgen, det er nemmere, sagde Karla og hun så sig tilbage. Det er så kedeligt, sagde David. Han havde lyst til oksekød og han rodede i køledisken.

- Så tar vi roastbeef, sagde Karla og hun lagde en oksesteg ned i kurven og en pakke rullepølse og en pakke spegepølse og hun ledte efter mayonnaise og Frans stod ved siden af hende med en pose blandede bolcher i hånden og David lagde en dåse ananas i kurven og lidt efter en agurk og sild og kakaomælk og tilsidst stillede de sig op i køen ved et af kasseapparaterne og Karla lagde en plade flødechokolade med nødder ned i kurven. (s. 194)

Karla styrer efter, hvad der er sundt, nemt og økonomisk: æbler og købefrikadeller. David tænker på, hvad han har lyst til at sætte til livs uden at kere sig om vitaminer, tilbederingstid eller pris: vin, rejer, oksekød, kakaomælk. Karla giver efter, hun lader sig forføre af det lystbetonede, eftersom flødechokoladen med nødder sikkert er, hvad hun har lyst til at spise, og ikke hvad hverken husholdningsbudgettet eller den slanke linje tilsiger.

Et af problemerne ved den kønnede arbejdsdeling er lige præcis, at kvinden og manden kommer i interessekonflikt i forhold til dét reproduktive arbejde, som er et fælles anliggende, her indkøb og madlavning, men det kunne ligeså godt være børnepasning eller rengøring. Og måden, som Baby viser det frem på her, er så uendeligt tydelig og genkendelig samtidig med, at den parataktiske opremsning af de uhyre dagligdags, men langt fra tilfældige, produkter får den til at træde frem som et næsten haptisk - føleligt - ordmaleri. Og det understreges også af, at både Karla og David i denne situation er forbrugere, ikke producenter, hvilket for så vidt placerer dem i det samme senkapitalisiske, forbrugeristiske hamsterhjul. For den reproduktive sfære bliver fra 60'erne og frem, hvilket man også ser hos f.eks. Vita Andersen og Sonja Åkesson (særlig prægnant i Åkessons digtsamling Pris fra 1968), stadigt mere præget af senkapitalistisk forbrugerisme, et tema som dele af receptionen har haft svært ved at forstå som noget, der havde et kritisk potentiale.

Vita Andersens tekster fra 70'erne, f.eks. digtsamlingen Tryghedsnarkomaner og novellesamlingen Hold kæft og vær smuk, blev nedvurderet for deres angivelige upoetiskhed ("knækprosa" kaldte Brostrøm den slags litteratur) og private banalitet ("menstruationslyrik" var Dan Turells persiflage), ${ }^{\mathrm{r}}$ endskønt både Andersen og 
Åkesson arbejder med pop-art-teknikker, der skærende præcist beskriver forbrugerismens fortvivlede begærsmaskine. Her et lille uddrag af Vita Andersen-klassikeren "Hun ser godt ud":2

64 Hun går på gaden i sin frokostpause uden overtøj og med sin pung $\mathrm{i}$ hånden

hun kan se sig selv i butikkernes vinduer hun ser godt ud bukserne strammer perfekt om enden hun har lyst til at købe noget hun tænker på når hun kommer hjem det skal blive en god aften for hende og ungerne hun skal også se at få malet entreen om den er så mørk hun havde malet den hawaiigul for at den skulle blive lysere hun må male den om en dag hun får tid hun har set en entre i Bo Bedre (s. 16)

Man kan udmærket læse det hér digt som et digt, der handler om, at kvinden er slavegjort af et udefrakommende (fallisk) blik. At hun er underkastet senkapitalistiske markedsstrategier (købetrang). Senere i teksten finder vi også ud af, at hun er ensom og ulykkeligt drikker portvin og spiser Yankie-bar, når ungerne er lagt i seng. Og man skal på ingen måde formindske den ulykkelighed, som Vita Andersens personaer er præget af. Den er dyb, de er ensomme, svigtede, kærlighedshungrende, forladte og deprimerede. Men det, som får den her tekst til at virke, er, vil jeg påstå, ordet "hawaiigul", og den i digtet senere optrædende "Yankie-bar", hvilket rummer hele digtets egen analyse af forbrugssituationens dobbelthed og gør det til et stykke popkunst. De masseproducerede hverdagsting, som ikke er kunst, træder frem med grafisk prægnans og afspejler præcis den senkapitalistiske begærsøkonomis dobbelthed. Kvinden er selvfølgelig "fanget" af reklamens magt, men - vil jeg tilføje hun begærer også tingene: De stramtsiddende cowboybukser er lækre og opnåelige. Alle kan købe en Yankie-bar, alle kan købe cowboybukser - i det mindste på kredit.

\section{'En lighed mellem mig og kartofler'}

Sonja Åkessons digtsamling om forbrugerismens kønnethed - den allerede nævnte Pris - består af readymades, hvis sammenstilling beskriver et forbrugssamfund, der, som Jenny Tunedal skriver, "riktar sig till den goda hustrun som ska stå vid spisen og laga god mat, satsa på kärleken, dölja papiljotterna under en söt spetsmössa, ta av den olkädsamma martyrglorian och inte bry sitt lilla huvud med politik" (s. 7). Et hovednummer i samlingen er langdigtet "Fantasifylld korv", som er en lang montage af slogans, reklamer og citater fra diverse ugebladsartikler, der på en virkelig sjov og sarkastisk, men også klaustrofobisk måde udstiller de performativer, som den forbrugende husmoder konstant bombarderes af, samtidig med at formsproget, linjebrud, fragmenteringen, rytmen og brugen af versaler ligner 
den, Gertrude Stein bruger i Tender Buttons, verdenslitteraturens første værk, hvor den kvindelige livsverdens accesscories er omdrejningspunktet. Som hos Thorup og Andersen får det hverdagsgenstandene til at træde frem på en taktil og ja, faktisk ny måde:

64 Kvinna vill ha manlig chef

Gris vill ha sällskap

Vill ni ha oss i julklapp?

Et skepp kommer lastat med

NYA BILAR

Korgkärren er kul. Och behändig.

Vattenstol - en så'n måste ni ansolut ha

TÄNK DEJ SJÄLV I DOM STÖVLARNA (s. 64)

Sonja Åkesson var også konkretist, men det er ikke sådan, hun er blevet læst før for ganske nylig. I det hele taget lider en stor del af 70'er-litteraturens kvindelige forfattere under kritikkens manglende forståelse af, hvad det betyder at skrive fra det reproduktive arbejdes sted, endskønt en af de bedste, Åkesson, nærmest stavede det ud for læserne. Husfrid hedder hendes vigtige gennembrudsdigtsamling fra 1963, hvori det nyklassiske digt "Äktenskapsfrågan" står, og det begynder sådan her:

6f Vara Vit Mans slav.

Vit Man vara snäll ibland, javisst

dammsuga golven och spela kort

med barnen i Helgen

Vit Man var på för Jävligt humör

Och svära fula ord

Många dagar

Vit Man inte tåla slarv.

Vit Man inte tåla stekat Mat.

Vit Man inte tåla Dum mening.

Vit Man får stora Anfall

Snubbla barnens pjäxor. (s. 44)

For en samtidig læser er det selvfølgelig ikke indiskutabelt etisk forsvarligt at sidestille den slavegjorte med de ydmygelser en hvid, svensk hjemmegående husmoder modtager fra den hvide hustyran, men med det sagt, er det en håndfast, sarkastisk udpegning af det reproduktive arbejdes absolutte marginalisering, der finder sted her. Og det er også en humoristisk fremstilling, hvilket den ikke bliver mindre virkningsfuld af.

Hendes "Självbiografi. Replik til Ferlinghetti", som også står at finde i Husfrid, er lige præcis en "replik til Ferlinghetti", idet hun skriver en selvbiografi, der svarer på hans digt "Autobiography”. At Åkesson var en stor beundrer af Beatdigtningen er ubetvivleligt, men digtet, som i egentlig forstand er en hypertekst, er bestemt ikke 
en ukritisk fejring af den amerikanske digters berømte digt. Her de første linjer af Ferlinghetti, henholdsvis Åkesson til sammenligning:

64 I am leading a quiet life

in Mike's Place every day

watching the champs

of the Dante Billiard Parlor

and the French pinball addicts.

I am leading a quiet life

on lower East Broadway.

I am an American.

I was an American boy.

(Ferlinghetti, 16)

Jag levar ett lugnt liv

på Drottninggatan 83 a på dagarne.

Snyter ungar och putsar golv

och kopparpottor

och kokar rotmos och pölsa.

Jag levar ett lugnt liv

i närheten av tunnelbanan.

Jag är svensk.

Jeg hade en svensk uppväxt.

(Åkesson, 53)

"Mike's Place" er skiftet ud med "Drottninggatan 83 a", billiardturnering og pinballmaskiner med gulvvask, snotaftørring, grydeopvask og tilberedning af rodfrugtmos og pølse, "lower East Broadway" er skiftet ud med "i närheten av tunnelbanan". Formen på digtene er den samme, men det uproduktive liv er skiftet ud med det reproduktive, hvilket ikke mindst sætter Ferlinghettis egomane dandyisme i relief.

Men den mest perspektivrige skildring af, hvilke radikale kræfter, der ligger i kim med indførelsen af den reproduktive sfære i poesien falder lidt senere i digtet, hvor tonen ikke længere er legende og muntert-sarkastisk, men smertefuld:

6f Jag sprang ut i den tidiga skymningen

Och ville sträcke handen genom himlen

Men skyndade tillbaka hem

För inte bränna vid potatisen.

Jag ser en likhet mellan mig och potatis.

Vid minsta källarljus dessa famlande stängler.

Men aktas för stötar.

Aktas för kyla. (s. 61) 
Her den tilsvarende passus hos Ferlinghetti:

$6 f$ I marched up Fifth Avenue

blowing on a bugle in a tight platoon

but hurried back to the Casbah

looking for my dog.

I see a similarity

between dogs and me.

Dogs are the true observers

walking up and down the world

thru the Molloy country. (s. 19)

Det første, man bør lægge mærke til, er Åkessons forandring og omvending af sammenligningen: "I see a similarity / between dogs and me", som hun erstatter med "Jag ser en likhet mellan mig och potatis", hvilket vender sammenligningsleddets retning om. Ferlinghetti kigger først på hunden, så på sig selv, Åkesson først på sig selv, så på kartoflen. Gør det en forskel? Ja, det gør det, for det omvender sammenligningens kilde og mål. Hos Ferlinghetti er det manden, der siger noget om hunden ud fra sig selv ("Dogs are true observers" - præcis som digtets jeg), hos Åkesson er det kartoflen, der siger os noget om det jeg, der vil række ud efter himlen, men skynder sig hjem, fordi hun kommer i tanke om, at kartoflerne måske brænder på.

Men de kartofler, der måske brænder på, fører derefter teksten videre fra angsten for mislykket madlavning til en udvidelse af billeddannelsen, der kun er mulig at fange, hvis man har et vist kendskab til kartoflens fænomenologi, hvad enhver husmoder naturligvis bør have. Mit eget kendskab til kartoflen stammer eksempelvis ikke kun fra dyrkning, opbevaring og tilberedning af kartofler, men i lige så høj grad fra Suhrs kogebog, hvor man făr god besked om, hvor skrøbelig en rodfrugt denne tilsyneladende så robuste fødevare er, hvis man ikke behandler den korrekt. Kartofler er i virkeligheden en af de mest giftige og mest sarte fødevarekilder, vi har. Hvis kartoflen får lys, bliver den grøn, og dette grønne er giftige alkaloider, som man selv i små mængder får meget ondt i maven af, og som man absolut ikke skal indtage i større stil. Når kartoflen får lys og/eller fugt, begynder den hurtigt at spire, og disse spirer er også fulde af gift. Dem skal man slet ikke spise, og selv hvis man skærer dem af, sidder der en giftrest tilbage. Den del af kartoffelplanten, der vokser over jorden, er også meget giftig. Desuden er kartoflen særdeles skrøbelig over for stød, der straks danner blåviolette pletter under skrællen, og kartoflen skal nok opbevares mørkt og køligt, men hvis den opbevares for køligt, begynder den at danne sukkerstoffer, der helt ændrer dens struktur og smag. Alt dette taget $\mathrm{i}$ betragtning er det et under, at mennesket og kartoflen har fået så nært et forhold til hinanden. Men hvis vi nu overfører kartoflens egenskaber til jeg'et, hvilket er, hvad Åkesson gør i denne sammenhæng, kan vi sige følgende om dette jeg: Straks jeg'et får det mindste "lys i sin kælder," begynder det at udvikle "famlende stængler" - en længsel efter noget. Jeg'et spirer altså ved det mindste lys i mørket, men spirerne er skrøbelige, brækker let og ved ikke, hvor de skal hen. Når jeg'et bliver stødt, får det blå mærker. Og hvis jeg'et fryser, ændrer det smag og struktur. Det er, hvad digtet ekspliciterer. 
Men dertil kommer, at kartoflen simpelthen er fuld af gift og det prototypiske eksempel på en plante med rhizomatisk rodvækst. Rødderne filtrer og gror i alle retninger. Den er desuden fattigmandskost, en billig spise og resultatet af kolonial import, den skal tilberedes for at smage godt og giver ru og røde hænder, når man skræller for mange af dem - og hvem véd - måske blå mærker, hvis man brænder den på.

Således genererer kartoffelsammenligningen en hel, kompleks livsverden, det reproduktive arbejdes livsverden, som bærer en dyb viden om tingene med sig som den produktive livsverden - der også er kapitalismens livsverden, hvor det som nævnt gælder om at købe billigt og sælge dyrt - anvender uden det reproduktive perspektivs etos. For kapitalen er produktionens bæredygtighed, dens reprocucérbarhed, i princippet fuldkommen ligegyldig. Vi udvinder de fossile brændstoffer, vi fælder træerne, vi ødelægger jordens mikroorganismer og hele klodens biodiversitet for profittens skyld. Alting har en pris.

Og så er vi tilbage ved Alfabets jeg, som står i køkkenet og skræller kartofler, mens hun tænker på atombomben. Hvad har kartoffelskrælning og atombomber med hinanden at gøre? Hvorfor er det allermest hverdagslige og det absolut ikkehverdagslige placeret over for hinanden i Christensens digt? Alfabet er blevet hyldet for sine "affirmative" kvaliteter, hvilket vel hænger sammen med digtets uimodsigelige skønhed og gentagelsen af "findes", men det er også et af de mest uhyggelige digte, som nogensinde er skrevet. Dels på grund af Hiroshima/Nagasaki-teksten, hvori kartoffelskrælningen befinder sig. Dels også på grund af digtsamlingens isnende afslutning:

Uf en flok børn søger ly i en hule

kun iagttaget stumt af en hare

som om de var børn i barndommens

eventyr hører de vinden fortælle

om de afbrændte marker

men børn er de ikke

der er ingen der bærer dem mere (s. 456)

Når der ikke er nogen til at bære børnene, er livet forbi. Reproduktionens virke afsluttet. At opretholde livet er reproduktivt arbejde, men det kan også være bæredygtigt arbejde i den forstand, at man ikke anvender flere ressourcer end de nødvendige, idet formålet med dette arbejde ikke er overskud, men opfyldelsen af basale, livsnødvendige behov. Det jeg, som står i sit køkken og skræller kartofler, repræsenterer livsnødvendigheden over for atombombens indbyggede løfte om altings ødelæggelse, det livsopretholdende, reproduktive arbejde overfor våbenproducenternes dødsteknologier. Det er en revolutionært virkende kartoffelskrælning, for som hos Thorup, Andersen og Åkesson syn- og sanseliggøres det usynliggjorte, reproduktive arbejde som rigtigt, virkeligt, værdifuldt arbejde. Og i Alfabets kontekst: Som et arbejde, hvis modsætning er døden. 


\section{Noter}

I Jf. Anne-Marie Mais genlæsning af Vita Andersen-receptionen. Ang. Åkesson se Henning og Björck.

2 Denne korte Vita Andersen-analyse står oprindelig som en del af min anmeldelse af Sille Kirketerp Berthelsens bog: Med hjertet \& kussen i laser - Et magtmenstruelt hævnskrift, der giver \#MeToo-kritikerne og andre med deres på det tørre svar på tiltale gennem Vita Andersens poesi (Friis).

\section{Litteratur}

Andersen, Vita (1977): Tryghedsnarkomaner, København: Gyldendal.

Bennett, Jane (2004): Vibrant Matter. A political ecology of things, Durham: Duke University Press. Björck, Amelie (2013): "Følelsernes materiale", i KRITIK 208, s. 60-67.

Braidotti, Rosi (2011): Nomadic Subjects: Embodiment and Sexual Difference in Contemporary. Feminist Theory, New York: Colombia University Press.

Christensen, Inger (2005): Samlede digte, København: Gyldendal.

Federici, Silvia (2004): Caliban and The Witch. Women, The Body and Primitive Accumulation, Brooklyn: Autonomedia.

Ferlinghetti, Lawrence (1958): A Coney Island of the Mind, New York: New Directions.

Friis, Elisabeth (2019): "Bukserne strammer de rigtige steder”, anmeldelse, i Eftertryk 17. juli 2019. Henning, Peter (2013): “100\% alvor, 100\% distance”, i KRITIK 208, s. 67-75.

James, Selma og Mariarosa Dalla Costa (1973): The Power of Women and the Subversion of the Community, Oakland: PM Press.

Mai, Anne-Marie (2013): "Vita revisited” i KRITIK 208, s. 4-18.

Nielsen, Hans-Jørgen (1971): “Så klipper hun alt håret af”, anmeldelse, i Information 11 maj 1971. Sontag, Susan (2003): Regarding The Pain of Others, New York: Farrar, Straus and Giroux.

Thorup, Kirsten (1971): I dag er det Daisy, København: Gyldendal.

Thorup, Kirsten (1973): Baby, København: Gyldendal.

Tunedal, Jenny (2006): Sonja Åkesson: Vara vit mans slav, Stockholm: Nordstedts.

Åkesson, Sonja (1963): Husfrid, Stockholm: Rabén och Sjögren.

Åkesson, Sonja (1968): Pris, Stockholm: Rabén och Sjögren. 